\section{Kidney \\ Blood Pressure Research}

Kidney Blood Press Res 2018;43:959-969

DOI: $10.1159 / 000490475$

Published onlıne: 12 June, 2018

Accepted: 30 May, 2018

This article is licensed under the Cre This article is licensed under the Creative Commons Attribution-NonCommercial-NoDerivatives 4.0 International License (CC BY-NC-ND) (http://www.karger.com/Services/OpenAccessLicense). Usage and dist
for commercial purposes as well as any distribution of modified material requires written permission.

Review

\title{
Diagnosis and Treatment of Metabolic Acidosis in Patients with Chronic Kidney Disease - Position Statement of the Working Group of the Polish Society of Nephrology
}

\author{
Marcin Adamczak ${ }^{a}$ Anna Masajtis-Zagajewska ${ }^{b} \quad$ Oktawia Mazanowskac

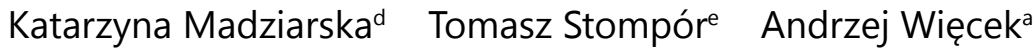 \\ aDepartment of Nephrology, Transplantation and Internal Medicine, Medical University of Silesia, \\ Katowice, bDepartment of Nephrology, Hypertension and Kidney Transplantation, Medical University \\ of Lodz, Lodz, 'Faculty of Medicine and Dentistry of the Wroclaw Medical University, Wroclaw, \\ ${ }^{\mathrm{d}}$ Department and Clinic of Nephrology and Transplant Medicine of the Wroclaw Medical University, \\ Wroclaw, eDepartment of Internal Medicine, Clinic of Nephrology, Hypertension and Internal Diseases \\ of the University of Warmia and Mazury in Olsztyn, Olsztyn, Poland
}

\section{Key Words}

Metabolic acidosis $•$ Guidelines $•$ Chronic kidney disease progression

\begin{abstract}
Metabolic acidosis is commonly found in patients with chronic kidney disease (CKD), and its causes are: impaired ammonia excretion, reduced tubular bicarbonate reabsorption and insufficient renal bicarbonate production in relation to the amount of acids synthesised by the body and ingested with food. As the consequence, numerous metabolic abnormalities develop, which may lead to dysfunction of several organs. In observational studies, it has been found that CKD patients with metabolic acidosis are characterised by faster progression of kidney disease towards end stage kidney failure, and by increased mortality. Results of interventional studies suggest that alkali therapy in CKD patients slows progression of kidney disease. In view of these facts, the members of "The Working Group of the Polish Society of Nephrology on Metabolic and Endocrine Abnormalities in Kidney Diseases" have prepared the following statement and guidelines for the diagnosis and treatment of metabolic acidosis in CKD patients. Measurement of bicarbonate concentration in venous plasma or venous blood to check for metabolic acidosis should be performed in all CKD patients and metabolic acidosis in these patients should be diagnosed when the venous plasma or venous blood
\end{abstract}

Marcin Adamczak, MD, PhD, Prof.
Department of Nephrology, Transplantation and Internal Medicine, Medical University of Silesia, Katowice, ul. Francuska 20/24, 40-027 Katowice (Poland)

Tel. + 4832 2552695, Fax + 4832 2553726, E-Mail madamczak1@op.pl 


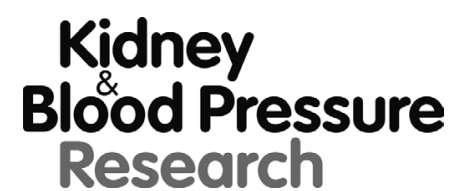

\begin{tabular}{l|l}
\hline Kidney Blood Press Res 2018;43:959-969 \\
\hline \begin{tabular}{l|l} 
DOI: 10.1159/000490475 & (c) 2018 The Author(s). Published by S. Karger AG, Basel \\
Published onlıne: 12 June, 2018 & ww.karger.com/kbr
\end{tabular}
\end{tabular}

Adamczak et al.: Metabolic Acidosis in Chronic Kidney Disease

bicarbonate concentration is lower than $22 \mathrm{mmol} / \mathrm{l}$. In patients with metabolic acidosis and CKD, oral sodium bicarbonate administration is recommended. The goal of such a treatment is to achieve a plasma or blood bicarbonate concentration equal to or greater than $22 \mathrm{mmol} / \mathrm{l}$.

(C) 2018 The Author(s)

Published by S. Karger AG, Basel

\section{Introduction}

Metabolic acidosis is a disorder of acid-base balance that results in a decrease of plasma bicarbonate concentration and in the lowering of $\mathrm{pH}$. In patients with chronic kidney disease (CKD), the causes of metabolic acidosis include: impaired ammonia excretion, decreased tubular reabsorption of bicarbonate and insufficient production of bicarbonate in relation to the amount of acids synthesised in the body and ingested with food. The loss of more than $80 \%$ of nephrons impairs base regeneration by the process of ammoniagenesis [1]. Although there is a compensatory increase in ammoniagenesis (by more than two-fold) in remaining nephrons, the plasma concentration of bicarbonate decreases [2]. The concentration of bicarbonate, as well as carbon dioxide, in the plasma may be decreased even in patients with moderate renal impairment. This early decrease of bicarbonate concentration is compensated by an increased concentration of chloride and does not lead to change of the anion gap [3]. In patients with more advanced CKD, plasma bicarbonate concentration is more reduced and in these patients an increase in the anion gap is observed $[3,4]$.

The $\mathrm{pH}$ value and concentration of bicarbonate in the plasma in CKD patients depend on glomerular filtration, supply of acidic foods (mainly proteins of animal origin, which include more methionine and cysteine), supply of alkaline foods (mainly vegetables and fruits), and efficiency of non-renal mechanisms (mainly in the gastrointestinal tract and bones) that compensate for metabolic acidosis [5 - 7].

In patients with CKD of different aetiologies in stages $1-4$ and 5 not yet requiring dialysis and not treated with sodium bicarbonate, the blood bicarbonate concentration shows a positive correlation with glomerular filtration rate (GFR) [8]. Metabolic acidosis usually develops when GFR is decreased to $20-30 \mathrm{ml} / \mathrm{min}$ [9]. More severe metabolic acidosis accompanies renal diseases in which tubulo-interstitial damage predominates [10]. Metabolic acidosis can also occur at earlier stages of CKD with the co-occurrence of renal tubular dysfunction, e.g. in hyporeninemic hypoaldosteronism accompanying longstanding diabetes [11 - 13].

Metabolic acidosis results in disorders of numerous metabolic processes leading to dysfunction of several organs.

Chronic metabolic acidosis increases protein catabolism and thus contributes to the pathogenesis of the malnutrition-inflammation-atherosclerosis (MIA) syndrome [14, 15]. Metabolic acidosis contributes to the development of the inflammatory process in CKD patients. In an acidic environment, the production of tumour necrosis factor-alpha (TNF- $\alpha$ ) by macrophages increases [16]. In children with CKD, metabolic acidosis leads to impairment of growth by inhibiting the secretion of growth hormone $(\mathrm{GH})$, reducing its activity in peripheral tissues and distorting the activity of the GH - insulin-like growth factor 1 (IGF-1) axis, with reduction of the serum concentrations of free IGF-1 and GH, and increase of plasma IGF-1 binding proteins $[17,18]$. In adults, these abnormalities may contribute to the pathogenesis of malnutrition. Metabolic acidosis adversely impacts calcium-phosphate metabolism in patients with CKD by reducing calcium receptor sensitivity as a result of the decrease in the intracellular $\mathrm{pH}$, and by stimulating the parathyroid glands to secrete parathyroid hormone [19]. It also contributes to the mobilisation of bone bases, stimulates osteoclasts, and inhibits the activity of osteoblasts [20]. In addition, metabolic acidosis stimulates bone turnover, thus increasing the risk of osteoporosis. Metabolic acidosis may increase the serum $\beta_{2}$-microglobulin concentration and contribute to the development of $\beta_{2}$-microglobulin amyloidosis [21]. In patients with CKD without diabetes, low plasma bicarbonate concentration and metabolic acidosis are factors influencing the severity of 


\section{Kidney \\ Blood Pressure Research}

insulin resistance, and alkalisation with sodium bicarbonate increases insulin sensitivity [22 - 24]. In patients with CKD who have hypertriglyceridemia, the administration of sodium bicarbonate results in the reduction of serum triglycerides concentration [25]. In CKD patients, metabolic acidosis impairs the peripheral conversion of thyroxine into triiodothyronine, which results in the reduction of the serum triiodothyronine concentration [26]. In addition, the results of animal experiments suggest that metabolic acidosis in patients with CKD increases the serum hepcidin concentration, and thus participates in the pathogenesis of anaemia of chronic disease $[27,28]$. It has been shown that in CKD patients treated with haemodialysis, metabolic acidosis increases the demand for erythropoiesis stimulating agents [29].

In view of the adverse effect of metabolic acidosis on the prognosis of CKD patients, the members of "The Working Group of the Polish Society of Nephrology on Metabolic and Endocrine Abnormalities in Kidney Diseases" have prepared the following statement and recommendations concerning the diagnosis and treatment of metabolic acidosis in such patients. These recommendations are summarized in Table 1 and Fig. 1.

\section{Recommendation 1}

Measurement of bicarbonate concentration in venous plasma or venous blood to check for metabolic acidosis should be performed in all patients with chronic kidney disease (expert opinion).

\section{Recommendation 2}

In patients with CKD stages 4 or 5 (not yet on renal replacement therapy), the determination of plasma or venous blood bicarbonate concentration should be carried out at least once a year (expert opinion).

Table 1. Recommendations for the diagnosis and treatment of metabolic acidosis in patients with chronic kidney disease

\begin{tabular}{|c|c|}
\hline Recommendation & Source of recommendation \\
\hline $\begin{array}{l}\text { 1. Measurement of bicarbonate concentration in venous plasma or venous blood to } \\
\text { check for metabolic acidosis should be performed in all patients with chronic } \\
\text { kidney disease }\end{array}$ & Expert opinion \\
\hline $\begin{array}{l}\text { 2. In patients with CKD stages } 4 \text { or } 5 \text { (not yet on renal replacement therapy), the } \\
\text { determination of venous plasma or venous blood bicarbonate concentration should } \\
\text { be carried out at least once a year }\end{array}$ & Expert opinion \\
\hline $\begin{array}{l}\text { 3. Metabolic acidosis in patients with chronic kidney disease should be diagnosed } \\
\text { when the venous plasma or venous blood bicarbonate concentration is lower than } \\
22 \mathrm{mmol} / \mathrm{l}\end{array}$ & $\begin{array}{l}\text { Recommendation based on } \\
\text { results of observational studies }\end{array}$ \\
\hline $\begin{array}{l}\text { 4. In patients with metabolic acidosis and chronic kidney disease, oral sodium } \\
\text { bicarbonate administration is recommended }\end{array}$ & $\begin{array}{l}\text { Recommendation based on } \\
\text { results of interventional studies }\end{array}$ \\
\hline $\begin{array}{l}\text { 5. The goal of treatment of metabolic acidosis in patients with chronic kidney } \\
\text { disease is to achieve a plasma or blood bicarbonate concentration equal to or } \\
\text { greater than } 22 \mathrm{mmol} / \mathrm{l}\end{array}$ & $\begin{array}{l}\text { Recommendation based on } \\
\text { results of interventional studies }\end{array}$ \\
\hline
\end{tabular}




\section{Kidney Blood Pressure Research}

\section{Commentary on recommendations 1 and 2}

Since metabolic acidosis often occurs in CKD patients, it is recommended that diagnostic tests for it should be carried out in all patients with CKD.

Analysis of the results of the NHANES III (The Third National Health and Nutrition Examination Survey) study indicates that metabolic acidosis (serum bicarbonate concentration below 22 $\mathrm{mmol} / \mathrm{l}$ ) is found in $19 \%$ of patients with CKD stage 4 [30]. Raphael et al. found metabolic acidosis (venous blood bicarbonate concentration below $22 \mathrm{mmol} / \mathrm{l}$ ) in $17.3 \%$ of CKD stages $2-4$ patients participating in the CRIC (Chronic Renal Insufficiency Cohort) study [31]. In a study performed in the Department of Nephrology, Transplantation and Internal Diseases, Medical University of Silesia in Katowice, metabolic acidosis (venous blood bicarbonate concentration below $22 \mathrm{mmol} / \mathrm{l}$ ) was diagnosed in $19.6 \%$ of CKD stages $1-5$ patients [8].

The prevalence of metabolic acidosis increases along with renal impairment. Clase et al. found blood bicarbonate concentration below $23 \mathrm{mmol} / \mathrm{l}$ in $6 \%$ of patients with CKD stage 3 and in 33\% of patients with CKD stages $4-5$ [30]. Similarly, Skiba et al. observed significant increase in the metabolic acidosis prevalence in patients with CKD stage 4 (44\% of patients) and with CKD stage 5 (63\% of patients) compared to patients with CKD stage 1 (10\% of patients) [8]. It is therefore recommended that patients with stage 4 or 5 CKD should have their venous serum or venous blood bicarbonate concentrations monitored at least once a year.

In order to determine metabolic acidosis in patients with CKD, it is recommended that the venous plasma or venous whole blood bicarbonate concentration should be measured. Due to the risk of bleeding, local complications associated with the arterial puncture and the need to spare arteries for the future access for hemodialysis, arterial blood sampling is not recommended for this purpose. It is important mind the potential impact of ischemia of the forearm while sampling venous blood due to transient venous stasis on blood/ plasma $\mathrm{pH}$ value and bicarbonate concentration. This phenomenon may lower $\mathrm{pH}$ and bicarbonate concentration of venous blood in the upper extremity and as a consequence lead to overdiagnosis of metabolic acidosis. For this reason, duration of ischemia must be minimalized and we suggest blood sampling by an experience personnel.

\section{Recommendation 3}

Metabolic acidosis in patients with chronic kidney disease should be diagnosed when the venous plasma or venous blood bicarbonate concentration is lower than $22 \mathrm{mmol} / \mathrm{l}$ (recommendation based on results of observational studies). 


\section{Kidney Blood Pressure Research}

Kidney Blood Press Res 2018;43:959-969

\begin{tabular}{l|l}
\hline DOI: $10.1159 / 000490475$ & (C) 2018 The Author(s). Published by S. Karger AG, Basel
\end{tabular}

Published onlıne: 12 June, 2018

www.karger.com/kb

Adamczak et al.: Metabolic Acidosis in Chronic Kidney Disease

\section{Commentary on recommendation 3}

Results of observational studies suggest that in patients with venous plasma or venous blood serum bicarbonate concentration below 21-23 mmol/l, more rapid CKD progression is observed.

In the observational study, MESA (The Multi-Ethnic Study of Atherosclerosis), which included patients with eGFR above $60 \mathrm{ml} / \mathrm{min}$ at baseline, a 35\% increase of more rapid progression of CKD risk (defined as the loss of more than 5\% of the initial GFR value per year) was observed in those patients with a serum bicarbonate concentration below 21 mmol/l, compared with patients with a serum bicarbonate concentration between 23 and $24 \mathrm{mmol} / \mathrm{l}[32]$. The retrospective observational study carried out by Shah et al. showed that for patients with a serum bicarbonate concentration below $22 \mathrm{mmol} / \mathrm{l}$, the risk of more rapid CKD progression (a decline to eGFR $15 \mathrm{ml} / \mathrm{min}$ or at least a $50 \%$ fall from the baseline eGFR) increased by $54 \%$ compared to patients with a serum bicarbonate concentration between 25 and $26 \mathrm{mmol} / \mathrm{l}$ [33]. In the CRIC study, which included patients with CKD stages $2-4$, patients with a serum bicarbonate concentration below $22 \mathrm{mmol} / \mathrm{l}$ were characterised by a $97 \%$ increase in the risk of more rapid CKD progression (i.e. the need for renal replacement therapy or at least $50 \%$ decrease in eGFR) compared to patients with a serum bicarbonate concentration between 22 and $26 \mathrm{mmol} / \mathrm{l}$ [34].

Results of observational studies also suggest increased mortality in patients with a plasma or venous blood bicarbonate concentration below 21-23 mmol/l.

In the study done by Navaneethan et al. [35], which included patients with stage $3-4$ CKD, mortality was $23 \%$ higher in patients with a serum bicarbonate concentration below $23 \mathrm{mmol} / \mathrm{l}$ compared to patients with a serum bicarbonate concentration between 23 and $32 \mathrm{mmol} / \mathrm{l}$. Among the participants of the NHANES III with CKD, a serum bicarbonate concentration below $22 \mathrm{mmol} / \mathrm{l}$ was associated with a more than two-fold increase of mortality compared to patients with a serum bicarbonate concentration between 26 and 30 $\mathrm{mmol} / \mathrm{l}$ [36]. In a prospective study of patients with CKD not requiring renal replacement therapy ( $57 \%$ of patients with stage 3 CKD), Kovesdy et al. showed that a bicarbonate serum concentration below $22 \mathrm{mmol} / \mathrm{l}$ was associated with a $43 \%$ increase in mortality compared to patients with a serum bicarbonate concentration between $26 \mathrm{mmol} / \mathrm{l}$ and $29 \mathrm{mmol} / \mathrm{l}$ [37].

In conclusion, results of observational studies indicate that patients with a venous plasma or venous blood bicarbonate concentration below $21-23 \mathrm{mmol} / \mathrm{l}$ are characterised by more rapid CKD progression and higher mortality. Therefore, in the current recommendations for CKD patients, the concentration of bicarbonate in the venous plasma or venous blood between these values, i.e. $22 \mathrm{mmol} / \mathrm{l}$, has been adopted as a threshold value for the diagnosis of metabolic acidosis.

\section{Recommendation 4}

In patients with metabolic acidosis and chronic kidney disease, the use of oral sodium bicarbonate is recommended (recommendation based on the results of interventional studies).

\section{Recommendation 5}

The goal of treatment of metabolic acidosis in patients with chronic kidney disease is to achieve a venous plasma or venous blood bicarbonate concentration equal to or greater than $22 \mathrm{mmol} / \mathrm{l}$ (recommendation based on results of interventional studies). 


\section{Kidney Blood Pressure Research}

Kidney Blood Press Res 2018;43:959-969

\begin{tabular}{l|l}
\hline DOI: $10.1159 / 000490475$ & (C) 2018 The Author(s). Published by S. Karger AG, Basel
\end{tabular}

Published onlıne: 12 June, 2018

www.karger.com/kbr

Adamczak et al.: Metabolic Acidosis in Chronic Kidney Disease

\section{Commentary on recommendations 4 and 5}

The first reports of beneficial effects of the combination of a low-protein diet with oral administration of sodium bicarbonate in patients with CKD were published as early as in the 1930s [38].

In recent years, the results of three clinical trials on the impact of alkali therapy on CKD progression have been published. De Brito-Ashurst et al. [39] conducted a randomised trial which included 134 patients with CKD stage 4 and a serum bicarbonate concentration between $16 \mathrm{mmol} / \mathrm{l}$ and $20 \mathrm{mmol} / \mathrm{l}$, who were treated with standard therapy or additionally received sodium bicarbonate at the average dose of $1.82 \mathrm{~g} /$ day. The authors of the study demonstrated that administration of sodium bicarbonate in CKD patients slows CKD progression measured by GFR reduction, reduces the number of patients requiring renal replacement therapy, and improves nutritional status [39]. Mahajan et al. [40] observed a much slower GFR decrease in patients with hypertensive nephropathy in the course of fiveyear treatment with sodium bicarbonate compared to patients receiving a similar amount of sodium as sodium chloride.

Based on results of available clinical trials we suggest an initial daily dose of 1-2 g of sodium bicarbonate. Subsequently, while monitoring the venous plasma and venous blood bicarbonate concentration, the dose of sodium bicarbonate should be increased until the target bicarbonate concentration, i.e. equal to or greater than $22 \mathrm{mmol} / \mathrm{l}$, is achieved. Due to the lack of data on the safety of sodium bicarbonate used in high doses, in the opinion of the authors a maximal daily dose of $6 \mathrm{~g}$ of sodium bicarbonate should not be exceeded.

It is believed that metabolic acidosis treatment using sodium bicarbonate in patients with CKD is well tolerated and safe.

Treatment of metabolic acidosis with sodium bicarbonate at the most commonly used doses, i.e. $2-3 \mathrm{~g} /$ day, may sometimes lead to the development of metabolic alkalosis. Therefore, in the course of alkali therapy, the plasma or venous blood bicarbonate concentration should be checked periodically to prevent the process of excessive alkalisation. Results of observational studies suggest that excessive alkalisation may be potentially dangerous. In the CRIC study, in patients with CKD stages $2-4$ with a serum bicarbonate concentration above $26 \mathrm{mmol} / \mathrm{l}$, an increase in mortality and in the incidence of heart failure were observed compared to patients with a serum bicarbonate concentration between 22 and $26 \mathrm{mmol} / \mathrm{l}$ [41]. Navaneethan et al. found increased mortality in patients with CKD stages $3-4$ and a serum bicarbonate concentration above $32 \mathrm{mmol} / \mathrm{l}$ in comparison to patients with a serum bicarbonate concentration between 23 and $32 \mathrm{mmol} / \mathrm{l}$. In this study, a two-fold prevalence of heart failure and chronic obstructive pulmonary disease was observed in patients with the serum bicarbonate concentration above $32 \mathrm{mmol} / \mathrm{l}$ compared to patients with a serum bicarbonate concentration between 23 and $32 \mathrm{mmol} / \mathrm{l}$ [35]. Taking this into account, it can be assumed that the increased mortality in patients with a serum bicarbonate concentration higher than 26 or $32 \mathrm{mmol} / \mathrm{l}$ in the quoted observational studies, respectively, may result from the co-occurrence of heart failure (administration of diuretics can cause hypokalemia, and subsequently lead to an increase in the concentration of bicarbonate in the serum), or the co-occurrence of chronic obstructive pulmonary disease (in the course of which elevated $\mathrm{pCO}_{2}$ is accompanied by a compensatory increase in the concentration of bicarbonate in the serum). However, given the above mentioned results of observational studies, the temporary cessation of sodium bicarbonate administration can be considered in clinical situations which can foster the development of metabolic alkalosis (e.g.: vomiting, hypokalemia).

Taking into consideration the fact that sodium bicarbonate contains sodium, it could be assumed that administration of sodium bicarbonate would lead to an increase in blood pressure. However, this was not the case in experimental studies, as well as, in the clinical trials in humans. Namely, experimental studies done in salt-dependent deoxycorticosterone 


\section{Kidney Blood Pressure Research}

Kidney Blood Press Res 2018;43:959-969

\begin{tabular}{l|l}
\hline DOI: $10.1159 / 000490475$ & (C) 2018 The Author(s). Published by S. Karger AG, Basel
\end{tabular}

Published onlıne: 12 June, 2018

www.karger.com/kbr

hypertensive rats (DOCA - salt-sensitive rats) and spontaneously hypertensive stroke prone rats suggested that sodium bicarbonate, in contrast, to sodium chloride - does not lead to the blood pressure elevation [42-44]. No blood pressure increase was observed in the study of De Bristo - Ashurst et al. [39]. The dose of sodium bicarbonate (1.82 g, containing $499 \mathrm{mg}$ sodium) used in this study provided an amount of sodium corresponding to only $10-14 \%$ of daily consumption. In addition, the meta-analysis of intervention studies carried out by Susantitaphong et al. [45] has shown that sodium bicarbonate supplementation in patients with CKD is not associated with the need to initiate antihypertensive treatment or with an increase in the number antihypertensive drugs used. In the 1970s, Husted et al. showed that oral sodium bicarbonate treatment in patients with CKD, as opposed to administration of $\mathrm{NaCl}$, did not lead to an increase in systolic blood pressure [46]. They stated that the administration of sodium in the form of sodium bicarbonate increased natriuresis, which allowed the maintenance of a normal body content of sodium. On the other hand, the increase in natriuresis as a result of exposure to sodium in the form of $\mathrm{NaCl}$ is smaller and insufficient for the compensation of increased sodium supply [46]. Sodium bicarbonate, in contrast to $\mathrm{NaCl}$, does not increase blood pressure either in healthy subjects or in patients with arterial hypertension [47].

The use of sodium bicarbonate in large doses may (extremely rarely) lead to an increase in the volume of the stomach (through the release of $\mathrm{CO}_{2}$ ) and even to rupture of the stomach wall. To prevent this complication, it is recommended that sodium bicarbonate is taken between meals [48].

Interventional study results indicate that oral administration of sodium citrate may be an alternative method of alkali therapy to treatment with sodium bicarbonate. During a twoyear observation of 59 patients with hypertensive nephropathy (eGFR ranging 20-60 ml/ $\mathrm{min}$ ) treated with sodium citrate for metabolic acidosis, Phisitkul et al. showed a reduction in the rate of decrease of eGFR from $3.8 \mathrm{ml} / \mathrm{min} /$ year to $1.9 \mathrm{ml} / \mathrm{min} /$ year [49]. However, sodium citrate increases absorption of aluminium from the gastrointestinal tract. Therefore, it should not be used in patients with significantly impaired renal function (especially while taking aluminium-containing phosphate binders, although these medications are almost never used nowadays). In addition, the use of sodium citrate does not lead to an increase of bicarbonate concentration in patients with liver damage, as the conversion of citrates into bicarbonates occurs mainly in the liver. The authors of the current recommendations do not have personal experience of the use of sodium citrate in alkali therapy.

In addition to pharmacological treatment, a diet rich in vegetables and fruits (the socalled "alkaline diet") may have a beneficial effect on metabolic acidosis in CKD patients [50-52]. Renoprotective effects of this diet has been found in patients with hypertensive nephropathy and CKD stage 1 [50]. Goraya et al. [53], in a study involving 71 patients with hypertensive nephropathy (eGFR $>90 \mathrm{ml} / \mathrm{min}$ ) and albuminuria, found that proteinuria did not worsen in patients following a diet with an increased content of fruits and vegetables, in contrast to patients not undergoing alkali therapy. In patients with CKD stage 3 and a concentration of $\mathrm{tCO}_{2}$ in the serum between $22 \mathrm{mmol} / \mathrm{l}$ and $24 \mathrm{mmol} / \mathrm{l}$ treated with sodium bicarbonate or following a diet with an increased content of fruits and vegetables, the decrease in eGFR (calculated based on creatinine and cystatin C plasma concentrations) over a three-year period, was lower than in those not receiving sodium bicarbonate or the abovementioned diet [54]. In an observational study of 76 non-diabetic patients with hypertensive nephropathy and GFR ranging between $15 \mathrm{ml} / \mathrm{min}$ and $29 \mathrm{ml} / \mathrm{min}$ taking angiotensin converting enzyme inhibitors, with serum potassium concentrations below $4.6 \mathrm{mmol} / \mathrm{l}$ and metabolic acidosis, Goraya et al. showed a similar degree of improvement of metabolic acidosis, reduction of albuminuria and reduction of GFR in patients treated with sodium bicarbonate and those receiving a diet enriched with fruits and vegetables [54]. Careful selection of patients participating in the study (i.e. without a tendency to hyperkalemia) and close monitoring of serum potassium concentrations reduced the risk of hyperkalemia in patients with impaired renal function even though a potassium-rich diet was ingested [55]. 


\section{Kidney Blood Pressure Research}

Scialla et al. showed that in patients at different CKD stages, a diet rich in vegetable protein increased the concentration of bicarbonate in the blood [56].

It should be kept in mind that the use of the so-called "alkaline diet", i.e. a diet rich in fruits and vegetables, in patients with CKD can potentially lead to hyperkalemia. It should also be noted that no studies have been conducted on the safety of a diet with an increased content of fruits and vegetables under the conditions of routine clinical practice (i.e. not under the conditions of a clinical trial). In clinical practice, a diet with an increased content of fruits and vegetables should be considered in CKD patients only in stages $1-2$.

\section{Limitations of the recommendations}

The existing data concerning the impact of the treatment of metabolic acidosis on the inhibition of CKD progression originate from single-centre studies, without randomisation, and including only small groups of patients $[57,58]$. Currently, three interventional studies involving a larger number of patients are being conducted: the UBI study (prospective, multicentre, randomised, aiming at recruitment of 600 patients with stage $3 b-4$ CKD and metabolic acidosis treated with sodium bicarbonate $v s$ sodium citrate vs placebo); the So - Bic study (prospective, single-centre, randomised trial with 200 patients with stage $3-4$ CKD and metabolic acidosis treated with sodium bicarbonate $v s$ placebo); and the NCT01452412 study (prospective, multicentre, randomised, involving 728 patients with stage $3 \mathrm{~b}-4$ CKD and metabolic acidosis treated with sodium bicarbonate vs placebo) [59 - 61].

The recommendations presented above do not cover patients undergoing renal replacement therapy. An important source of bicarbonate in the plasma in patients with CKD treated with haemodialysis is from the dialysate during haemodialysis sessions $[62,63]$. In these patients, normal or increased concentrations of bicarbonate in the plasma or venous blood are found (usually between 27 and $30 \mathrm{mmol} / \mathrm{l}$ ) immediately after haemodialysis [62, $63]$. This concentration is significantly reduced during the period between dialyses $[62,63]$. In patients with CKD receiving peritoneal dialysis, metabolic acidosis occurs rarely [64]. In renal transplant patients, the results of the few available observational studies suggest that metabolic acidosis is a risk factor for adverse prognosis in terms of graft and patient survival $[65,66]$. So far, there have been no interventional studies on treatment of metabolic acidosis which include a sufficiently large group of patients undergoing renal replacement therapy. Therefore, the routine use of sodium bicarbonate in patients undergoing renal replacement therapy is currently not recommended.

\section{Acknowledgements}

The authors would like to express their gratitude towards Prof. Jonathan Fox (from the The Glasgow Renal Unit, University of Glasgow) for the correction and critical review of the manuscript.

\section{Disclosure Statement}

M. Adamczak received lecture fee from Sanum Polska. The other authors declare no conflict of interest. 


\section{Kidney \\ Blood Pressure Research}

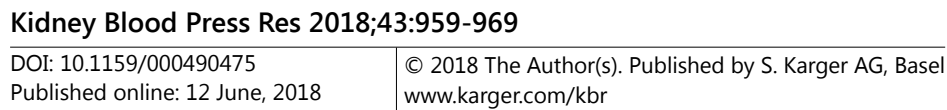

Adamczak et al.: Metabolic Acidosis in Chronic Kidney Disease

\section{References}

1 Wesson DE, Jo CH, Simoni J: Angiotensin II receptors mediate increased distal nephron acidification caused by acid retention. Kidney Int 2012;82:1184-1194.

- Han KH: Mechanism of the effects of acidosis and hypokalemia on renal ammonia metabolism. Electrolyte Blood Press 2011;9:45-49.

-3 Widmer B, Gerhardt RE, Harrington JT, Cohen JJ: Serum electrolyte and acid base composition. The influence of graded degrees of chronic renal failure. Arch Intern Med 1979;139:1099-1102.

4 Hakim RM, Lazarus JM: Biochemical parameters in chronic renal failure. Am J Kidney Dis 1988;11:238-247.

5 Dobre M, Rahman M, Hostetter TH: Current status of bicarbonate in CKD. J Am Soc Nephrol 2015;26:515523.

-6 Foley RN, Wang C, Ishani A, Collins AJ: NHANES III: Influence of race on GFR thresholds and detection of metabolic abnormalities. J Am Soc Nephrol 2007;18:2575-2582.

7 Scialla JJ, Anderson C: Dietary acid load: a novel nutritional target in chronic kidney disease? Adv Chr Kidney Dis 2013;20:141-149.

8 Skiba K, Szotowska M, Kolonko A, Adamczak M, Więcek A: Prevalence of metabolic acidosis in kidney transplant patients. Transpl Int 2013;26:S243.

-9 Viswanathan G, Sarnak MJ, Tighiouart H, Muntner P, Inker LA: The association of chronic kidney disease complications by albuminuria and glomerular filtration rate: a cross - sectional analysis. Clin Nephrol 2013;80:29-39.

10 Nath KA, Hostetter MK, Hostetter TH: Pathophysiology of chronic tubule-interstitial disease in rats. Interactions of dietary acid load, ammonia, and complement component C3. J Clin Invest 1985;76:667-675.

11 Sebastian A, Schambelan M, Lindenfeld S, Morris RC Jr: Amelioration of metabolic acidosis with fludrocortisone therapy in hyporeninemic hypoaldosteronism. N Engl J Med 1977;297:576-583.

12 van Nieuwkoop C, Ijpelaar DH, Bolk JH: Treating proteinuria in a diabetic patient despite hyperkalaemia due to hyporeninaemic hypoaldosteronism. Neth J Med 2007;65:75-77.

-13 Levine DZ, Iacovovitti M, Burns KD, Slater A: Distal tubule bicarbonate reabsorption in intact and remnant diabetic kidneys. Kidney Int 2000;57:544-549.

14 Kalantar - Zadeh K, Mehrotra R, Fouque D, Kopple JD: Metabolic acidosis and malnutrition - inflammation complex syndrome in chronic renal failure. Semin Dial 2004;17:455-465.

15 Mak RH: Effect of metabolic acidosis on branched-chain amino acids in uremia. Pediatr Nephrol 1999;13:319-322.

16 Bellocq A, Suberville S, Philippe C, Bertrand F, Perez J, Fouqueray B, Cherqui G, Baud L: Low environmental $\mathrm{pH}$ is responsible for the induction of nitric-oxide synthase in macrophages - evidence for involvement of nuclear factor kappa B activation. J Bioch Chem 1998;273:5086-5092.

17 Eustace JA, Astor B, Muntner PM, Ikizler TA, Coresh J: Prevalence of acidosis and inflammation and their association with low serum albumin in chronic kidney disease. Kidney Int 2004;65:1031-1040.

18 Brüngger M, Hulter HN, Krapf R: Effect of chronic metabolic acidosis on the growth hormone/IGF-1 endocrine axis: new cause of growth hormone insensitivity in humans. Kidney Int 1997;51:216-221.

19 Kraut JA, Kurtz I: Metabolic acidosis of CKD: diagnosis, clinical characteristics and treatment. Am J Kidney Dis 2005;45:78-993.

-20 Kopple JD, Kalantar-Zadeh K, Mehrotra R: Risks of chronic metabolic acidosis in patients with chronic kidney disease. Kidney Int Suppl 2005;95:21-27.

-21 Soniklan M, Gogusev J, Zingraff J, Loric S, Quednau B, Bessou G, Siffert W, Drueke TB, Reusch HP, Luft FC: Potential effect of metabolic acidosis on $\beta_{2}$ - microglobulin generation: in vivo and in vitro studies. J Am Soc Nephrol 1996;7:350-356.

22 Kobayashi S, Maesato K, Moriya H, Ohtake T, Ikeda T: Insulin resistance in patients with chronic kidney disease. Am J Kidney Dis 2005;45:275-280.

23 Mak RH: Effect of metabolic acidosis on insulin action and secretion in uremia. Kidney Int 1998;54:603607.

24 Bellasi A, Di Micco L, Santoro D. Marzocco S, De Simone E, Cozzolino M, Di Lullo L, Guastaferro P, Di Iorio B, UBI study investigators: Correction of metabolic acidosis improves insulin resistance in chronic kidney disease. BMC Nephrol 2016;17:158. 


\section{Kidney \\ Blood Pressure Research}

25 Mak RH: Effect of metabolic acidosis on hyperlipidemia in uremia. Pediatr Nephrol 1999;13:891-893.

26 Iglesias P, Diez JJ: Thyroid dysfunction and kidney disease. Eur J Endocrinol 2009;160:503-515.

-27 Mizumoto C, Kawabata H, Uchiyama T, Sakamoto S, Kanda J, Tomosugi N, Takaori-Kondo A: Acidic milieu augments the expression of hepcidin, the central regulator of iron homeostasis. Int J Hematol 2012;96:701709.

28 Babitt JL, Lin HY: Mechanism of anaemia in CKD. J Am Soc Nephrol 2012;23:1631-1634.

29 Diskin CJ, Stokes TJ, Dansby LM, Radcliff L, Carter TB: Can acidosis and hyperphosphataemia result in increased erythropoietin dosing in haemodialysis patients? Nephrology 2006;11:394-399.

-30 Clase CM, Kiberd BA, Garg AX: Relationship between glomerular filtration rate and the prevalence of metabolic abnormalities: Results from the Third National Health and Nutrition Examination Survey (NHANES III). Nephron Clin Pract 2007;105:178-184.

-31 Raphael KL, Zhang Y, Ying J, Greene T: Prevalence of and risk factors for reduced serum bicarbonate in chronic kidney disease. Nephrology 2014;19:648-654.

-32 Driver TH, Shlipak MG, Katz R, Goldenstein L, Sarnak MJ, Hoofnagle AN, Siscovick DS, Kestenbaum B, de Boer IH, Ix JH: Low serum bicarbonate and kidney function decline: The multi ethnic study of atherosclerosis (MESA). Am J Kidney Dis 2014;64:534-541.

33 Shah SN, Abramowitz M, Hostetter TH, Melamed M: Serum bicarbonate levels and the progression of kidney disease: A cohort study. Am J Kidney Dis 2009;54:270-277.

-34 Dobre M, Yang W, Chen J, Drawz P, Hamm LL, Horwitz E, Hostetter T, Jaar B, Lora CM, Nessel L, Ojo A, Scialla J, Steigerwalt S, Teal V, Wolf M, Rahman M, CRIC Investigators: Association of serum bicarbonate with risk of renal and cardiovascular outcomes in CKD: A report from the chronic renal insufficiency cohort (CRIC) study. Am J Kidney Dis 2013;62:670-678.

-35 Navaneethan SD, Schold JD, Arrigain S, Jolly SE, Wehbe E, Raina R, Simon JF, Srinivas TR, Jain A, Schreiber MJ Jr, Nally JV Jr: Serum bicarbonate and mortality in stage 3 and stage 4 chronic kidney disease. Clin J Am Soc Nephrol 2011;6:2395-2402.

-36 Raphael KL, Zhang Y, Wei G, Greene T, Cheung AK, Beddhu S: Serum bicarbonate and mortality in adults in NHANES III. Nephrol Dial Transplant 2013;28:1207-1213.

37 Kovesdy CP, Anderson JE, Kalantar-Zadeh K: Association of serum bicarbonate levels with mortality in patients with non-dialysis dependent CKD. Nephrol Dial Transplant 2009;24:1232-1237.

38 Lyon DM, Dunlop DM, Steward CP: The alkaline treatment of chronic nephritis. Lancet 1931;2:1009-1013.

-39 de Brito-Ashurst I, Varagunam M, Raftery MJ, Yaqoob MM: Bicarbonate supplementation slows progression of CKD and improves nutritional status. J Am Soc Nephrol 2009;20:2075-2084.

40 Mahajan A, Simoni J, Sheather SJ, Broglio KR, Rajab MH, Wesson DE: Daily oral sodium bicarbonate preserves glomerular filtration rate by slowing its decline in early hypertensive nephropathy. Kidney Int 2010;78:303-309.

-41 Dobre M, Yang W, Pan Q, Appel L, Bellovich K, Chen J, Feldman H, Fischer MJ, Ham LL, Hostetter T, Jaar BG, Kallem RR, Rosas SE, Scialla JJ, Wolf M, Rahman, CRIC Study Investigators: Persistent high serum bicarbonate and the risk of heart failure in patients with chronic kidney disease (CKD): A report from the Chronic Renal Insufficiency Cohort (CRIC) study. J Am Heart Assoc 2015;4:e001599.

42 Ziomber A, Machnik A, Dahlmann A, Dietsch P, Beck FX, Wagner H, Hilgers KF, Luft FC, Eckardt $\mathrm{KU}$, Titze J: Sodium-, potassium-, chloride-, and bicarbonate-related effects on blood pressure and electrolyte homeostasis in deoxycorticosterone acetate-treated rats. Am J Physiol Renal Physiol 2008;295:F1752-F1763.

43 Kunes J, Zicha J, Jelínek J. Kunes J, Zicha J, Jelínek J: The role of chloride in deoxycorticosterone hypertension: selective sodium loading by diet or drinking fluid. Physiol Res 2004;53:149-154.

44 Luft FC, Steinberg H, Ganten U, Meyer D, Gless KH, Lang RE, Fineberg NS, Rascher W, Unger T, Ganten D. Effect of sodium chloride and sodium bicarbonate on blood pressure in stroke-prone spontaneously hypertensive rats. Clin Sci (Lond) 1988;74:577-585.

45 Susantitaphong P, Sewaralthahab K, Balk EM, Jaber BL, Madias NE: Short - and long - term effects of alkali therapy in chronic kidney disease: a systematic review. Am J Nephrol 2012;35:540-547.

46 Husted FC, Nolph KD, Maher JF: $\mathrm{NaHCO}_{3}$ and $\mathrm{NaCl}$ tolerance in chronic renal failure. J Clin Invest 1975;56:414-419. 


\section{Kidney \\ Blood Pressure Research}

Adamczak et al.: Metabolic Acidosis in Chronic Kidney Disease

47 Luft E, Zemel MB, Sowers JA, Fineberg NS, Weinberger MH: Sodium bicarbonate and sodium chloride: effects on blood pressure and electrolyte homeostasis in normal and hypertensive man. J Hypertens 1990;8:663-670.

48 Łoniewski I, Wesson DE: Bicarbonate therapy for prevention of chronic kidney disease progression. Kidney Int 2014;85:529-535.

49 Phisitkul S, Khanna A, Simoni J, Broglio K, Sheather S, Rajab MH, Wesson DE: Amelioration of metabolic acidosis in patients with low GFR reduced kidney endothelin production and kidney injury, and better preserved GFR. Kidney Int 2010;77:617-623.

50 Cianciaruso B, Pota A, Pisani A, Torraca S, Annecchini R, Lombardi P, Capuano A, Nazzaro P, Bellizzi V, Sabbatini M: Metabolic effects of two low protein diets in chronic kidney disease stage 4-5 - a randomized controlled trial. Nephrol Dial Transplant 2008;23:636-644.

51 Goraya N, Wesson DE: Dietary management of chronic kidney disease: protein restriction and beyond. Curr Opin Nephrol Hypertens 2012;21:635-640.

52 Kopple JD: National kidney foundation K/DOQI clinical practice guidelines for nutrition in chronic renal failure. Am J Kidney Dis 2001;37:66-70.

53 Goraya N, Simoni J, Jo CH, Wesson DE: Dietary acid reduction with fruits and vegetables or bicarbonate attenuates kidney injury in patients with a moderately reduced glomerular filtration rate due to hypertensive nephropathy. Kidney Int 2012;81:86-93.

54 Goraya N, Simoni J, Jo CH, Wesson DE: Treatment of metabolic acidosis in patients with CKD stage 3 chronic kidney disease with fruits and vegetables or oral sodium bicarbonate reduces urine angiotensinogen and preserves glomerular filtration rate. Kidney Int 2014;86:1031-1038.

55 Goraya N, Simoni J, Jo CH, Wesson DE: A comparison of treating metabolic acidosis in CKD stage 4 hypertensive kidney disease with fruits and vegetables or sodium bicarbonate. Clin J Am Soc Nephrol 2013;8:371-381.

-56 Scialla JJ, Appel LJ, Wolf M, Yang W, Zhang X, Sozio SM, Miller ER 3rd, Bazzano LA, Cuevas M, Glenn MJ, Lustigova E, Kallem RR, Porter AC, Townsend RR, Weir MR, Anderson CA, Chronic Renal Insufficiency Cohort-CRIC Study Group: Plant protein intake is associated with fibroblast growth factor 23 and serum bicarbonate in patients with CKD: The Chronic Renal Insufficiency Cohort Study. J Ren Nutr 2012;22:379388.

57 Kraut JA, Madias NE: Metabolic acidosis of CKD: an update. Am J Kidney Dis 2016;67:307-317.

58 Raphael KL: Approach to the treatment of chronic metabolic acidosis in CKD. Am J Kidney Dis 2016;67:696702.

59 Di Iorio B, Aucella F, Conte G, Cupisti A, Santoro D: A prospective, multicenter, randomized, controlled study: the correction of metabolic acidosis with use of bicarbonate in chronic renal insufficiency (UBI) study. J Nephrol 2012;25:437-440.

60 Gaggl M, Cejka D, Plischke M, Heinze G, Fraunschiel M, Schmidt A, Hörl WH, Sunder-Plassmann G: Effect of oral sodium bicarbonate supplementation on progression of chronic kidney disease in patients with chronic metabolic acidosis: study protocol for a randomized controlled trial (SoBic-Study). Trials 2013;14:196.

61 ClinicalTrials.gov: Placebo-controlled randomized clinical trial of alkali therapy in patients with chronic kidney disease. URL: https://clinicaltrials.gov/ct2/show/NCT01452412.

-62 Misra M: Pro: higher serum bicarbonate in dialysis patients is protective. Nephrol Dial Transplant 2016;31:1220-1224.

-63 Chauveau P, Rigothier C, Combe C: Con: higher serum bicarbonate in dialysis patients is protective. Nephrol Dial Transplant. 2016;31:1226-1229.

64 Vashistha T, Kalantar-Zadeh K, Molnar MZ, Torlén K, Mehrotra R: Dialysis modality and correction of uremic metabolic acidosis: relationship with all-cause and cause-specific mortality. Clin J Am Soc Nephrol 2013;8:254-264.

65 Park S, Kang E, Park S, Kim YC, Han SS, Ha J, Kim DK, Kim S, Park SK, Han DJ, Lim CS, Kim YS, Lee YP, Kim YH: Metabolic acidosis and long-term clinical outcomes in kidney transplant recipients. J Am Soc Nephrol 2017;28:1886-1897.

66 Gojowy D, Adamczak M, Skiba K, Bartmańska M, Kolonko A, Więcek A: Metabolic acidosis and outcome in patients long term after kidney transplantation. J Am Soc Nephrol 2016;27:275A. 